\title{
ТЕРМОМОДЕРНІЗАЦІЯ БАГАТОКВАРТИРНИХ БУДИНКІВ
}

\section{THERMAL MODERNIZATION OF APARTMENT BUILDINGS}

Пахолюк О.А., к.т.н., доц., Самчук В.П., к.т.н., доц. , Чапюк О.С., к.т.н., доц. (Луцький національний технічний університет), Зорук С.О., інженер (Ерланген, Німеччина)

Pakholiuk O.A., Ph.D. in Engineering, Associate Professor, Samchuk V.P., Ph.D. in Engineering, Associate Professor, Chapiuk O.S., Ph.D. in Engineering, Associate Professor (Lutsk National Technical University), Zoruk S.O., engineer (Erlangen, Bundesrepublik Deutschland)

Проаналізовано стан житлового фонду в Україні та програми підвищення їх енергоефективності. Розглянуто заходи з підвищення енергоефективності у пакетах Фонду енергоефективності.

The energy intensity of Ukraine's economy is significant. In such conditions, the potential for energy saving measures is great and should be implemented in all types of economic activity.

There were 45,500 old and 16,800 emergency homes in Ukraine. The vast majority of such buildings have three to five floors. They are prefabricated or brick, built in the postwar years in large cities until the mid-70s of the twentieth century. Today, these houses have critical indicators of physical wear.

The housing sector is second only to industry in terms of energy consumption. It was in it that the significant potential for energy savings was concentrated. This condition of buildings leads to significant energy costs for their maintenance.

To realize the potential of energy saving in the residential sector, laws were adopted regulating housing and communal services, commercial energy accounting, property rights in apartment buildings and energy efficiency of buildings. In 2018, the Energy Efficiency Fund began its work. Its purpose is to provide tools for thermal renovation of apartment buildings with condominiums. Until recently, the state program "Warm Loans" and the donor program IQ Energy also operated. In addition to state programs, there are local programs to support energy efficiency. Today, the Energy Efficiency Fund is the only government program that works to improve the energy efficiency of apartment buildings with condominiums.

In 2017, the Law of Ukraine on Energy Efficiency of Buildings was adopted. The certificate is produced within the framework of the energy audit and is a prerequisite for obtaining compensation for energy efficiency measures. Until December 2020, the database of energy efficiency certificates was maintained by the State Agency for Energy Efficiency and Energy Saving of Ukraine. At the moment, all certificates are registered by energy auditors and stored on the Portal of the state electronic system in the field of construction. 
In addition to the energy efficiency certificate, a reference report to the building's energy certificate is required to apply to the Energy Efficiency Fund. The annexes additionally provide more detailed information, including information on the costeffectiveness of recommendations for improving the energy efficiency of the building, as well as data on the characteristics of enclosing structures, engineering systems of the building and recommendations for improving energy efficiency, including a list of measures.

Ключові слова: енергоаудит, термомодернізаиія, Фонд енергоефективності, програма «Енергодім»

Keywords: energy audit, thermal modernization, Energy Efficiency Fund, «Energodim» program

За даними Міжнародного енергетичного агентства [1] станом на 2017 рік енергоємність, виміряна в перерахунку на первинну енергію та ВВП, в Україні складала 0,27 кг нафтового еквіваленту. При цьому середній показник у країнах, що розвиваються, складав 0,123 , у світі - 0,119, в Європі - 0,109 кг нафтового еквіваленту (рис. 1). Це свідчить про значну енергомісткість нашої економіки. У таких умовах потенціал заходів 3 енергозбереження $є$ значним і повинен реалізовуватись у всіх видах економічної діяльності.

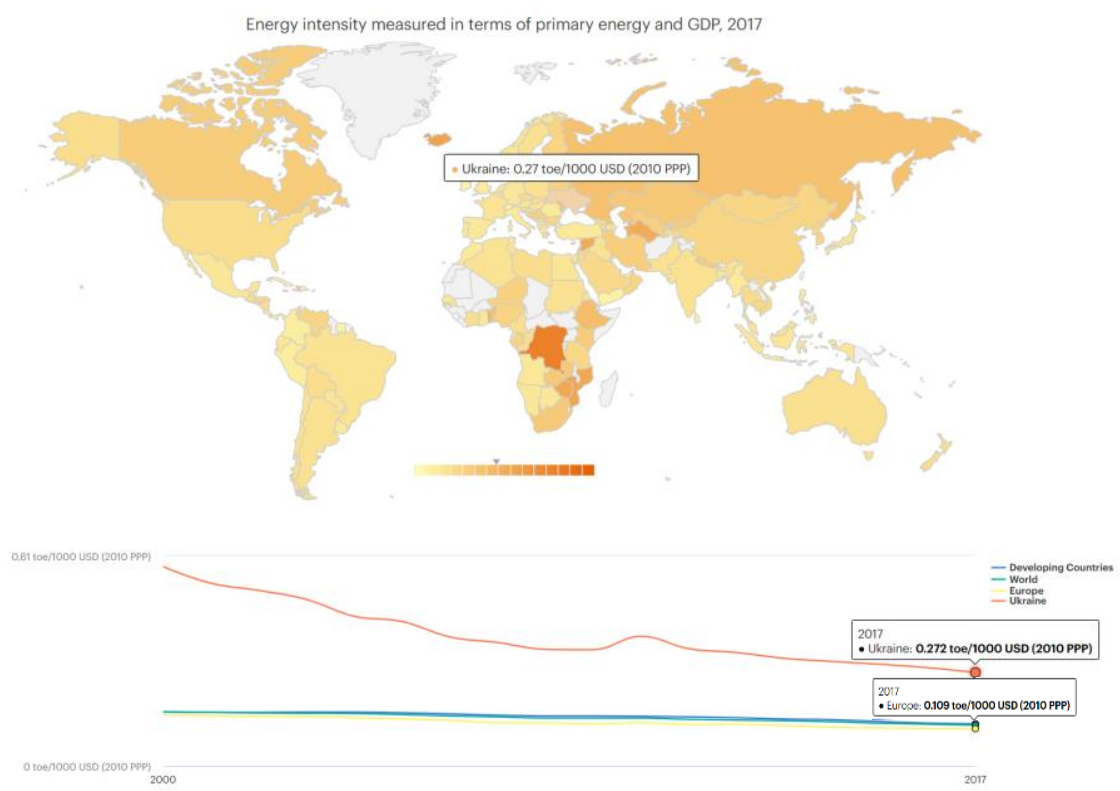

Рис. 1. Енергоємність, виміряна в перерахунку на первинну енергію та ВВП, 2017 рік [1] 
«За даними Державної служби статистики, на 1 січня 2019 р. в Україні нараховувалося 45,5 тис. старих і 16,8 тис. аварійних будинків. Переважна більшість таких будівель трьох-п'яти поверхів, панельні або цегляні, споруджені у післявоєнні роки у великих містах включно до середини 70-х pp. минулого сторіччя i на сьогодні мають критичні показники фізичного зносу. За інформацією Державної служби статистики, станом на 1 січня 2020 р. в Україні з 200 тис. багатоквартирних будинків майже 12\% було зведено в 1919-1945 pp., кожен четвертий будинок - у 1946-1960 pр., ще майже чверть - у 60-х рр. Понад 67 тис. будинків збудовані протягом 1960-1980 рр.» [2].

Житловий сектор є другим, після промисловості, за обсягами споживання енергоресурсів. Саме в ньому був зосереджений значний потенціал енергозбереження. Такий стан будівель призводить до значних витрат енергії на їх обслуговування.

Для реалізації потенціалу енергозбереження у житловому секторі було прийнято закони, що регламентують житлово-комунальні послуги, комерційний облік енергоносіїв, права власності у багатоквартирних будинках та енергетичну ефективність будівель. У 2018 році розпочав свою роботу Фонд енергоефективності, метою якого $є$ надання інструментів для термореновації багатоквартирних будинків 3 ОСББ. Також до недавнього часу діяли державна програма «Теплі кредити» i донорська програма IQ Energy. Крім державних, існують місцеві програми підтримки енергоефективності. На сьогодні Фонд енергоефективності $€$ єдиною державною програмою, яка працює 3 підвищенням енергоефективності багатоквартирних будівель, у яких створено ОСББ.

Базово у роботі фонду закладено правильну концепцію проведення комплексної термомодернізації будівель, оскільки тільки у такому випадку можна очікувати реального ефекту від впровадження енергоефективних заходів. Стартовою точкою у процесі термомодернізації $\epsilon$ прийняття правильних рішень із впровадження тих чи інших заходів. Для цього однією $з$ обов'язкових умов є проведення енергетичного аудиту. Лише проведення такого аудиту дасть можливість комплексно оцінити стан будівлі (iі конструктивних елементів, інженерних мереж), особливості експлуатації, енергоспоживання. При детальному підході до обстеження об'єкту стають зрозумілими системні помилки та можливості їх виправлення. Процедура енергетичного аудиту може бути проведена протягом усього року, однак додаткові обстеження (тепловізійне, температури теплоносіїв, якість утеплення інженерних мереж та ін.) $є$ можливим провести лише під час опалювального періоду. Це не обмежує енергоаудиторів, оскільки такі обстеження лише доповнюють процедуру енергоаудиту, а не є його основними інструментами.

Із прийняттям у 2017 році Закону України Про енергетичну ефективність будівель для «будівель, в яких здійснюється 
термомодернізація, на яку надається державна підтримка та яка має наслідком досягнення класу енергетичної ефективності будівлі не нижче мінімальних вимог до енергетичної ефективності будівлі» [3] обов'язковою $є$ сертифікація енергетичної ефективності. Виготовлення сертифікату відбувається в межах енергоаудиту і $\epsilon$ обов'язковою умовою для отримання компенсації за проведення енергоефективних заходів. До грудня 2020 р. базу сертифікатів енергетичної ефективності вело Державне агентство 3 енергоефективності та енергозбереження України. На даний момент усі сертифікати реєструються енергоаудиторами та зберігаються на Порталі державної електронної системи у сфері будівництва. Портал інтенсивно вдосконалюється, враховуються побажання та зауваження аудиторів до його роботи.

Крім сертифікату енергетичної ефективності обов'язковим для подачі заявки до Фонду енергоефективності $\epsilon$ рекомендаційний звіт до енергетичного сертифікату будівлі. У додатках до нього зазначаються детальніші відомості, включаючи інформацію про економічну ефективність рекомендацій щодо підвищення рівня енергетичної ефективності будівлі, а також наведено дані про характеристики огороджувальних конструкцій, інженерних систем будівлі та рекомендації щодо підвищення рівня енергетичної ефективності, включаючи перелік заходів та інформацію щодо їх вартості.

Для проведення енергоефективних заходів Фонд пропонує пакети «А» та «Б». Кожен 3 пакетів містить обов’язкові та додаткові заходи. Із повним переліком заходів можна ознайомитись у додатку 2 до Програми підтримки енергомодернізації багатоквартирних будинків «ЕНЕРГОДІМ» https://energodim.org/wp-content/uploads/2020/12/Perelik-zakhodiv-zenerhoefektyvnosti-paket-A-paket-B.pdf.

Значна вартість проведення заходів дозволяє розділити їх за значенням та важливістю на пакети і типи заходів. У межах кожного пакету $є$ заходи, обов'язкові до впровадження у межах даного пакету, якщо відсутні підстави для їх виключення з цього переліку, а також додаткові, впровадження яких є рекомендованим, але не обов’язковим.

Логіка пакетів полягає у першочерговому впровадженні заходів, що відразу суттєво впливають на споживання енергоносіїв, а отже їх вартість у платіжках мешканців. Першочерговим $\epsilon$ встановлення вузлів комерційного обліку теплової енергії, без яких будь яка мова про чисельне визначення витрат чи ефективності є неможливою.

Система опалення та гарячого водопостачання, особливо у будинках 3 централізованим їх забезпеченням, є основною витратною частиною. Тому в першу чергу проводяться заходи 3 їх модернізації, особливо у неопалювальних приміщеннях. Базовим $є$ встановлення індивідуального теплового пункту із забезпеченням погодного регулювання та балансування системи опалення 3 допомогою автоматичних 
балансувальних клапанів. Утеплення чи заміна з нормованим утепленням трубопроводів системи опалення та гарячого водопостачання в неопалювальних приміщеннях довершують цей комплекс заходів. Впровадження заходів з пакету «А» дозволить суттєво знизити витрати за порівняно невеликий кошт. Окупність заходів по цьому пакету залежно від типу та стану будинку складає, як правило, 1-2 роки. Прогнозований ефект від пакету - 25-35\% економії енергоносіїв. Зазвичай у межах пакету «А» стараються також провести заміну вікон та зовнішніх дверей у місцях загального користування чи облаштувати тамбури зовнішнього входу. Це дозволить підвищити температуру на сходовій клітині на 3-5 градусів, що підвищить комфорт у квартирах.

Пакет «Б» носить назву «Комплексний» і може впроваджуватись як продовження термомодернізаційних заходів пакету «А» або як самостійний пакет. Він містить усі обов'язкові заходи пакету «А», а також розширений заходами з утеплення основних зовнішніх огороджувальних конструкцій: стін, горищ і дахів, перекриття підвалу. Заміна вікон та зовнішніх дверей у місцях загального користування чи облаштування тамбурів зовнішнього входу разом із утепленням огороджувальних конструкцій дозволяють створити нерозривний утеплений контур, який $\epsilon$ однією з базових вимог до утеплення будівель. Це також дозволить змінити налаштування теплового пункту, що додатково зменшить втрати. Додаткові заходи пакету «Б» дозволять мешканцям утеплити та засклити балкони, замінити вікна у квартирах, модернізувати систему опалення, гарячого водопостачання, освітлення та вентиляції. Особливої уваги заслуговують заходи із встановлення вузлів розподільного обліку теплової енергії на потреби опалення або розподілювачів теплової енергії у квартирах. Цей захід разом із встановленням автоматичних регуляторів температури повітря на опалювальних приладах завершує заходи 3 модернізації системи опалення i дає безпрецедентні можливості індивідуального регулювання умов комфортності та індивідуального обліку спожитої енергії.

Окупність заходів пакету «Б» та їх вартість $є$ значно вищими у порівнянні $з$ пакетом «А», однак вони дозволяють значно скоротити витрати i привести будівлю до нормованих значень класу енергоефективності, визначених ДБН В.2.6-31:2016 та наказом №260 Міністерства розвитку громад та територій України.

Після проведення енергоаудиту та складання рекомендаційного звіту 3 описом проекту у відповідності до пакету заходів «А» чи «Б» оформляється перша заявка до Фонду енергоефективності. Після цього проводиться компенсація 70\% від вартості енергоаудиту. Така процедура дозволяе максимально здешевити для мешканців процедуру аудиту та прискорити прийняття рішень про початок робіт з термомодернізації. 
Для допомоги об'єднанням співвласників багатоквартирних будинків (ОСББ) у підготовці документації, роботі з мешканцями та підрядниками, впровадженні заходів Фондом енергоефективності було запроваджено інститут проектних менеджерів та проведено ряд навчальних заходів для ïx підготовки. На даний момент компенсація від фонду за роботу проектних менеджерів тимчасово призупинена, однак їх робота вкрай необхідна більшості ОСББ для якісного та швидкого просування шляхом термомодернізації їх будинків.

3 огляду на вищевказане можна зробити висновки, що хоча житловий фонд знаходиться у не найкращому стані, та $є$ дієві механізми його термомодернізації з компенсацією частини коштів від державного фонду. Це дозволить зменшити енергоспоживання житлових багатоквартирних будинків, покращити умови проживання та продовжити термін їх експлуатації.

\section{Список використаної літератури}

1. Report extract. Energy intensity. URL: https://www.iea.org/reports/sdg7-dataand-projections/energy-intensity (дата звернення: 10.05.2021).

2. Беззуб I. Комплексна реконструкція застарілого житлового фонду: українські реалії та зарубіжний досвід. Громадська думка про правотворення. 2021. № 1 (206). C. 14-25. URL: http://nbuviap.gov.ua/images/dumka/2021/1.pdf. (дата звернення: 10.05.2021).

3. Закон України Про енергетичну ефективність будівель. URL: https://zakon.rada.gov.ua/laws/show/2118-19\#Text. (дата звернення: 10.05.2021).

\section{References}

1. Report extract. Energy intensity. URL: https://www.iea.org/reports/sdg7-dataand-projections/energy-intensity (date of application: 10.05.2021).

2. Bezzub I. Kompleksna rekonstruktsiia zastariloho zhytlovoho fondu: ukrainski realii ta zarubizhnyi dosvid. Hromadska dumka pro pravotvorennia. 2021. № 1 (206). P. 14-25. URL: http://nbuviap.gov.ua/images/dumka/2021/1.pdf. (date of application: 10.05.2021).

3. Zakon Ukrainy Pro enerhetychnu efektyvnist budivel. URL: https://zakon.rada.gov.ua/laws/show/2118-19\#Text. (date of application: 10.05.2021). 